\title{
Soil properties and storage of organic carbon in the land use pasture and forest
}

\author{
Propiedades del suelo y la acumulación de carbono orgánico en los usos \\ del suelo pasto y bosque
}

Salomón Barrezueta-Undaㅜ; Kelvin Velepucha-Cuenca² ${ }^{2}$ Luis Hurtado-Flores ${ }^{3}$; Edwin Jaramillo-Aguilar ${ }^{4}$

\begin{tabular}{l}
\hline \multicolumn{2}{c}{ ARTICLE DATA } \\
\hline 1 Ph.D. Universidad Técnica de Machala, Machala, Ecua- \\
dor, sabarrezueta@utmachala.edu.ec \\
2 Ing. Agrónomo. Universidad Técnica de Machala, Macha- \\
la, Ecuador, kavelepucha_est@utmachala.edu.ec \\
3 MSc. Universidad Técnica de Machala, Machala, Ecuador, \\
lhurtado@utmachala.edu.ec \\
${ }^{4} \quad \begin{array}{l}\text { MSc. Universidad Técnica de Machala, Machala, Ecuador, } \\
\text { ejaramillo@utmachala.edu.ec }\end{array}$
\end{tabular}

Cite: Barrezueta-Unda, S.; Velepucha-Cuenca, K.; HurtadoFlores, L.; Jaramillo-Aguilar, E. (2019). Soil properties and storage of organic carbon in the soil uses pasture and forest. Revista de Ciencias Agrícolas. 36(2): 31-45. doi: https://doi. org/10.22267/rcia.193602.116

Received: December 31, 2018.

Accepted: April 11, 2019.

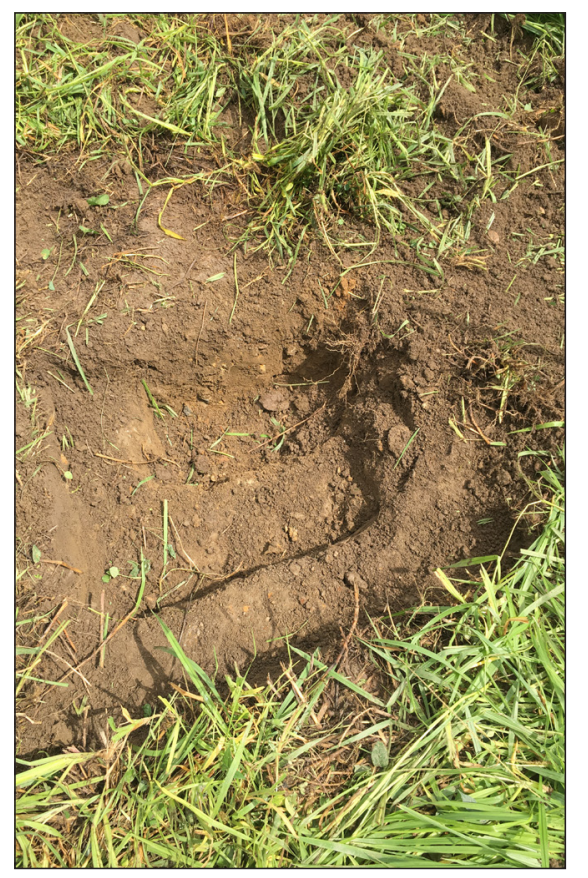

ABSTRACT

Soil is probably one of the natural resources most vulnerable to climate change. Composes most of the carbon stock in terrestrial ecosystems. The aims of this study were: to characterize the use of pastureland and native forest in two sites in El Oro province (Ecuador), based on their physical, chemical, and biological properties, and to compare the Soil Organic Carbon (SOC) stock at three depths. For this purpose, plots were established in Brachiaria sp pastures and native forests in the coastal area of Machala, Santa Inés site (SI), and the mountains of Chilla, Cune site $(\mathrm{CN})$. Soil sampling was done at three depths $(\mathrm{C} 1=0-10 \mathrm{~cm}$; $\mathrm{C} 2=10-20 \mathrm{~cm} ; \mathrm{C} 3=20-3 \mathrm{~cm})$. The SI soils showed significance (p-value $<0,05)$ among the stored SOC layers. The highest stored SOC value was for SI forest ( $\mathrm{C} 1,36,30$ megagrams-Mg C ha $^{-1}$ ), in an alkaline $\mathrm{pH}$ and clay loam texture. In CN soils, stored COS revealed no significance between layers, and values ranged from $27,64 \mathrm{Mg} \mathrm{ha}^{-1}\left(\mathrm{C}_{1}, \mathrm{CN}_{\text {forest }}\right)$ to $35,01 \mathrm{Mg} \mathrm{C}^{-1} \mathrm{ha}^{-1}\left(\mathrm{C}, \mathrm{CN}_{\text {pasture }}\right)$, in an acidic $\mathrm{pH}$, sandy loam texture and high levels of Fe (761,71-938,34 $\left.\mathrm{mg} \mathrm{kg}^{-1}\right)$. Soil properties play an important role in stored SOC levels; therefore, sequestration of SOC must be considered to develop optimal pasture management.

Keywords: soil carbon sequestration; bulk density; organic matter; soil texture.

\section{RESUMEN}

El suelo es probablemente uno de los recursos naturales más vulnerables al cambio climático. Compone la mayor parte de las reservas de carbono en los ecosistemas terrestres. Los objetivos de este estudio fueron: caracterizar el uso de los pastizales y el bosque nativo en dos sitios de la provincia de El Oro (Ecuador), basándose en sus propiedades físicas, químicas y biológicas, y comparar la reserva de carbono orgánico del suelo (SOC) a tres profundidades. Para ello se establecieron parcelas en pastizales y bosques nativos de Brachiaria sp. en la zona costera de Machala, sitio de Santa Inés (SI), y en las montañas de Chilla, sitio de Cune (CN). El muestreo del suelo se realizó a tres profundidades (C1 $=0-10 \mathrm{~cm} ; \mathrm{C} 2=10-20 \mathrm{~cm} ; \mathrm{C} 3=20-3 \mathrm{~cm}$ ). Los suelos del SI mostraron significación (valor $\mathrm{p}<0,05$ ) entre las capas SOC almacenadas. El mayor valor SOC almacenado fue para el bosque SI (C1,36,30megagramos-Mg C ha- 1$)$, en un $\mathrm{pH}$ alcalino y textura franco-arcillosa. En los suelos CN, el COS almacenado no reveló ninguna significación entre las capas y los valores oscilaron entre 27,64Mg ha-1(C1, CNforest) y 35,01 Mg C ha-1 (C3, CNpasture), en un pH ácido, 
textura franco-arenosa y altos niveles de Fe (761,71-938,34 mg kg-1). Las propiedades del suelo desempeñan un papel importante en los niveles de SOC almacenados; por lo tanto, debe considerarse el secuestro de SOC para desarrollar una gestión óptima de los pastos.

Palabras clave: secuestro de carbono en el suelo; densidad aparente; materia orgánica; textura del suelo.

\section{INTRODUCTION}

The capacity of soils to store or sequester organic carbon $(\mathrm{OC})$ represents one of their main functions (Wiesmeier et al., 2019). In this context, soil organic carbon (SOC) is generally lower in tropical and subtropical zones, about soils located in a temperate climate (Jiménez and Lal, 2006). This is the result of increased $\mathrm{OC}$ flow from plant biomass and microbial biomass into soils and increased rainfall and temperature conditions that accelerate carbon mineralization (de Koning et al., 2003; Novara et al., 2018). Other factors, such as slope and clay content, have an equal impact on SOC, regardless of climate (Takoutsing et al., 2016), as well as on the physical, chemical, and biological properties of the soil.

On the other hand, changes in land use are the second most important cause of the emission of greenhouse gases such as carbon dioxide, which occurs with greater intensity in tropical and subtropical areas (Don et al., 2011; Lal, 2015). The main land-use change is from forests to grasslands, which is the most widespread agricultural system on the planet and the livelihood of one million families (FAO, 2017; Lorenz and Lal, 2018).

In the year 2010, the area occupied by forests on the planet was 4,03 billion hectares, representing approximately $30 \%$ of the total area of arable land (Lorenz and Lal, 2018). The same percentage corresponded to grasslands, which included: natural pastures, scrublands, and forage crops (Lefèvre et al., 2017).

Meyer et al. (2018) consider pastures to be an important store of $\mathrm{SOC}$, due to the constant input of
OC from the root zone, where a significant amount of raw biomass is produced and continuously regenerated. The decomposition of the root biomass of pastures greatly influences the nutrient cycle, due to microbial action and consequently increases the accumulation of SOC (Liang et al., 2019; Rees et al., 2005). However, this depends on soil texture, soil topography, and climate (Liang et al., 2016). Other OC inputs to the soil originate from the excreta of grazing animals (Tilman et al., 2002).

Ecuador's native forest area decreased from $14,587,771$ hectares in 1990 to 12,753,387 hectares in 2014 (FAO, 2014; MAE, 2015), with agriculture being the main factor of change, mainly the use of pastureland, which in 2010 was 4,840,926.62 hectares, including both permanent and temporary pastures (INEC, 2011).

The replacement of native forest by pasture in the soils of Ecuador, mainly in the areas with tropical climates (coast, Andean foothills and the Amazon) has had negative effects such as soil erosion, or a decrease in the level of organic matter (Koning et al., 2003). Therefore, it has caused the loss of levels of SOC stored in the first $30 \mathrm{~cm}$ of the soil (Rhoades et al., 2000; Bravo et al., 2017). Although some studies in Ecuador have shown the opposite in temperate climate conditions (Andean highlands), where stored SOC levels increased (de Koning et al., 2003; Hamer et al., 2013).

Therefore, the aims of this research were: characterize the land uses of pasture and native forest in two sites in El Oro province (Ecuador), according to their physical, chemical, and biological properties and compare the storage of organic soil carbon at three depths. 


\section{MATERIALS AND METHODS}

Study area. The research was conducted in the province of El Oro, located in the south of Ecuador, at the following sites: Santa Inés Experimental Farm (SI) in Machala (03⒈ $17^{\prime} 16$ "LS; 79 $54^{\prime} 05^{\prime \prime}$ LO) and the Cune (CN) in Chilla (033'15" LS; $\left.79^{\circ} 60^{\prime} 46^{\prime \prime} \mathrm{LO}\right)$. The average annual temperature is $24,87^{\circ} \mathrm{C}$ at sea level for $\mathrm{SI}$ and $21,1^{\circ} \mathrm{C}$ between 550 and $1100 \mathrm{~m}$ altitude for CN. The annual precipitation was $708,4 \mathrm{~mm}$ and $1755 \mathrm{~mm}$ for SI and CN respectively; with rainfall between December to May and low rainfall from June to November (Luna-Romero et al., 2018)

The soils are of alluvial origin with a predominance of the Entisol (SI) and Inceptisol (CN) orders (Moreno et al., 2016). Santa Inés is located on a coastal plain and the Comuna Cune in the southwestern foothills of the Andes, with slopes that decrease in altitude from north to south (Baldock, 1982).

Slope, climate, and soil subgroups are the main factors that characterized each site (Table 1). The type of agronomic management was: intensive double-purpose (meat/milk), with frequent use of contact herbicides such as Paraquat to control weeds and chemical fertilizers such as muriate of potassium and urea. The pasture area was partially covered by scattered trees such as Samanea saman in SI and Laurus nobilis in CN, which provided shade for the cattle.

Sample Design. Within each site, a 3ha plot of land was delimited, cultivated with Brachiaria sp, which were codified as the land uses: $\mathrm{SI}_{\text {pasture }}$ and $\mathrm{CN}_{\text {pasture }}$. Along with the pastures, other plots of $2 \mathrm{ha}$ of native forest land use were demarcated, which were coded as $\mathrm{SI}_{\text {fores }} \mathrm{t}$ and $\mathrm{CN}_{\text {forest }}$. The predominant species in the forests were Cordia alliodora, Prosopis sp, Triplaris cumingiana, Pseudosamanea guachapele, Swietenia macrophylla, Roystonea regia, Drimys winteri, Inga sp, citronella mucronata, Brosimum alicastrum, Cordia alliodora and Aegiphila alba (Horstman et al., 2018).

In each plot, soil samples were collected. For this purpose, two types of sampling were carried out depending on the topography of the land. In SI, four $30 \mathrm{~m}$ long transects were delimited, spaced at $50 \mathrm{~m}$ ( 2 in the pasture, 2 in the forest), in which the sampling points (SP) were at zero, 15 , and $30 \mathrm{~m}$. For $\mathrm{CN}$ the transects (3 in the pasture, 2 in the forest), were L-shaped with direction to the slope of the hill. The SP was taken at zero and $25 \mathrm{~m}$ vertically and from 25 to $50 \mathrm{~m}$ horizontally, at a distance of $50 \mathrm{~m}$ between transects.

Table 1. Main characteristics of climate and soil of the Santa Inés and Cune sites.

\begin{tabular}{lll}
\hline \multicolumn{1}{c}{ Características } & \multicolumn{1}{c}{ Santa Inés (SI) } & \multicolumn{1}{c}{ Cune (CN) } \\
\hline Weather ${ }^{1}$ & Warm tropical & Humid sub-tropical \\
Slope (\%) & $0-2$ & $5-20$ \\
Soil order & Entisol & Inceptisol \\
Soil subgroup ${ }^{2}$ & Aquic Dystrustepts & Typic Haplanthrepts \\
Dry soil color ${ }^{3}$ & 10 YR 6/1 & 10YR4/2 \\
Land use & pasture (30 years); forest (>50 years) & pasture (20 years); forest (>50 years) \\
\hline${ }^{1}$ Kopper classification; ${ }^{2}$ Villaseñor et al.,(2015); ${ }^{3}$ Munsell Color (1994).
\end{tabular}


Then, undisturbed soil samples were taken in $100 \mathrm{~cm}^{3}$ \pm 2 metal cylinders, inserted vertically into the soil at three depths every $0,10 \mathrm{~m}$ in the SP. For this purpose, $0.20 \mathrm{~m}$ wide steps were formed (Figure 1 ). At the end, the samples were coded as layer 1 (C1) of $0-0,10 \mathrm{~m}$, layer 2 (C2) of $0,10-0,20 \mathrm{~m}$ and layer 3 (C3) of 0,20 $0,30 \mathrm{~m}$.

Soil analysis. At each sampling point and layer, $1,5 \mathrm{~kg}$ of soil was taken, which was air-dried for 72 hours, then crushed and sieved with $2 \mathrm{~mm}$ mesh, for the determination of the granulometry carried out by the Bouyoucus hydrometer method (Monroe et al., 2016). The $\mathrm{pH}$ determined in saturation paste with water is in the ratio of $1: 2,5$. Phosphorus (P) and potassium $(\mathrm{K})$ were determined with the Olsen method modified to pH 8,5 (Olsen and Sommers, 1982). Calcium (Ca), iron (Fe), and magnesium $(\mathrm{Mg})$ were determined through the extraction of KCl 1 N (USDA-NRCS, 2014). Analyses performed in the soil and plant tissue laboratories of the Ecuadorian Agency for Phytosanitary Regulation and Control.

Measurement of total flora and colimetry in the soil. A sample composed of $200 \mathrm{~g}$ of soil from the first layer was also collected for microbiological analysis of total flora and colometry. From the sample, $10 \mathrm{~g}$ were taken, to proceed by serial dilutions of the soil in a saline buffer solution $\left(\mathrm{K}_{2} \mathrm{HPO}_{4}\right.$ and $\left.\mathrm{NaCl}\right)$, to be planted in Petri dishes with agar plate counter (Merck, Massachusetts, USA) for total flora counting and with Macconkey (TM Media, Rajasthan, India) for colimetry (OrtízMaya et al., 2017). They were then transferred to the hatchery at $38^{\circ} \mathrm{C}$ for 24 and $48 \mathrm{~h}$ for total flora and colimetry counts respectively, in total colonyforming units per gram of soil ( $\mathrm{CFU} \mathrm{g}^{-1}$ ). Estimation made in a Leica digital colony counter model 3327 (Leica, Colorado, USA).

Calculation of stored soil organic carbon. With undisturbed soil samples, the bulk density (Bd) was obtained, which was determined by dividing the weight of the oven-dried sample at $105^{\circ} \mathrm{C}$ for $48 \mathrm{~h}$, for the volume of the cylinder (Equation 1) as suggested by Walkley and Black (1934).

$$
B d=\frac{D s}{C V}
$$

Dónde: $\mathrm{Bd}=$ bulk density $\left(\mathrm{Mg} \mathrm{m}^{3}\right)$, Ds=weight of the dry sample inside the cylinder, $\mathrm{CV}=$ cylinder volume.
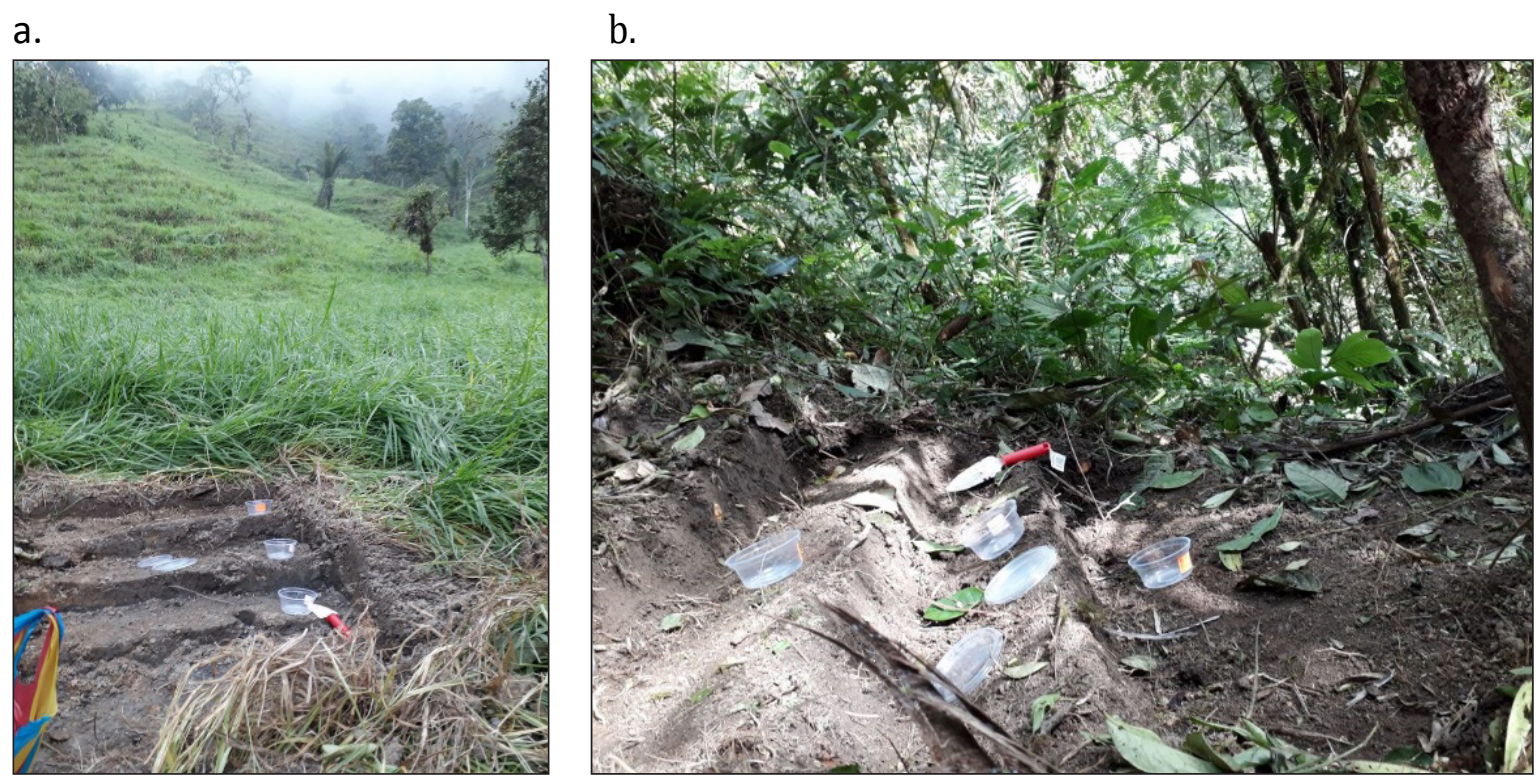

Figure 1. Soil sampling in different land uses. a) pasture (Cune); b) forest (Cune). 
The determination of $\mathrm{OC}\left(\mathrm{g} \mathrm{kg}^{-1}\right)$ was made by wet digestion with potassium dichromate (Walkley and Black, 1934). The amount of SOC stored was calculated (Equation 2), by multiplying by the $\mathrm{Bd}$ (mega grams-Mg $\mathrm{m}^{3}$ ), the depth (d) of soil sampling $(0.10 \mathrm{~m})$, the OC between 1000 and by $10,000 \mathrm{~m}^{2}$ factor corresponding to one hectare (Chen et al., 2019). Thus, Equation (3) provides the total SOC stock in the soil. The use of some correction factor for soil particles $>2 \mathrm{~mm}$, as suggested by Chen et al., (2019) and Reyna-Bowen et al. (2019), was ruled out because there was no stone in the sampled soils. The $\mathrm{Bd}$ and SOC determinations were performed at the soil laboratory of the Technical University of Machala.

$$
\begin{gathered}
\text { SOC stock }\left(M g h a^{-1}\right)=B d * d *\left(\frac{O C}{1000}\right) * 10000 \\
\text { Total SOC stock }\left(M g h a^{-1}\right)=\sum_{i=1}^{i=n} S O C \text { stock }
\end{gathered}
$$

Statistical analysis. All statistical testing was done with SPSS software, version 23,0 (SPSS, 2013). For physical, chemical, and biological soil properties and stored COS values, the statistical mean, standard error of the mean, and ranges were calculated. An analysis of variance (ANOVA) was carried out to find out if there are statistical differences between the land uses under study and the sampling depths. For the properties, flora total, colimetry, Bd, clay, and SOC stock, the Tukey test $(\mathrm{p}<0,05)$ was applied, by land use. To establish correlations indicating whether soil nutrients have an incidence on SOC, the Pearson 1\% and 5\% correlation analysis by land use was used between stored SOC and soil properties such as $\mathrm{pH}, \mathrm{P}, \mathrm{K}, \mathrm{Ca}$, $\mathrm{Mg}$ and Fe.

\section{RESULTS AND DISCUSSION}

Soil characteristics. The averages obtained from the physical and chemical properties of the soil are presented in Table 2, with their respective analysis.
Soil particles in SI were very tight between silt (pasture, 300 - 353,33g kg-1; forest, 413,33 423,33. $\mathrm{kg}^{-1}$ ), and sand (pasture, 256,67 - 270,00g $\mathrm{kg}^{-1}$; forest, 246,67 - 296,67 $\mathrm{g} \mathrm{kg}^{-1}$ ). In clay, the ranges were wider (pasture, 352,67 - 443,33g kg-1; forest, $283,33-330 \mathrm{~g} \mathrm{~kg}^{-1}$ ) and increased values between 20 and $30 \mathrm{~cm}(\mathrm{C} 3)$, with respect to the first layer. In $\mathrm{CN}$, soils showed high values of sand ranging from 592,56 - 640,67. $\mathrm{gg}^{-1}$ (pasture) to 592,17 $603,33 \mathrm{~g} \mathrm{~kg}^{-1}$ (forest) and while maximum values of clay (pasture, 129,78 - 157,11 $\mathrm{g} \mathrm{kg}^{-1}$; forest, 197,83 - 227,83. kg-1) and silt (pasture, 224,44 - 250,33g $\mathrm{kg}^{-1}$; forest, 170 - 205,50 $\mathrm{g} \mathrm{kg}^{-1}$ ), were lower than those determined for SI soils. The distribution of soil particles that allowed the classification into textured soils: clayey and loamy loam in $\mathrm{SI}_{\text {pasture }}$ loam in $\mathrm{SI}_{\text {forest }}$, and sandy loam for $\mathrm{CN}_{\text {pasture }}$ and $\mathrm{CN}_{\text {forest. }}$ This information coincides with the results of previous research in the soils of El Oro province (Villaseñor et al., 2015; Barrezueta-Unda et al., 2018). Moreno et al., (2016) point out the high percentages of sand in the first $30 \mathrm{~cm}$, in the foothills of the western Andean range, is a product of the runoff caused by the rain that transported the clay to the lower areas of the Ecuadorian coast.

The chemical reaction of the soil was different in both locations. In SI, the soil was more alkaline in the grass ( $\mathrm{pH} \mathrm{8,76} \mathrm{-} \mathrm{9,06),} \mathrm{concerning} \mathrm{the}$ use of forest soil ( $\mathrm{pH} 7,54-8,98)$. In $\mathrm{CN}$, the $\mathrm{pH}$ range varied towards acidity, with little variation between soil uses and depth (pasture 5,31 - 5,37; forest 5,19-5,27). Similar results were found by Potthast et al. (2012) in Ecuadorian soils with a tendency towards alkalinity (pH 7-8) in the coastal region and $\mathrm{pH}$ ranges from 4,2 (forest) to 5,3 (pasture) in the foothills and Andean paramo areas. Makeschin et al. (2008), also found this difference in $\mathrm{pH}$ in Ecuadorian soils and related it to Ca levels (high on the coast, low in the mountains) and to the high level of Fe in the mountains.

The levels of $\mathrm{K}$ were high in $\mathrm{SI}_{\text {pasture' }} \mathrm{SI}_{\text {forest' }}$ and 
Table 2. General soil properties by land use and depth.

\begin{tabular}{|c|c|c|c|c|c|c|c|c|c|}
\hline \multirow{2}{*}{$\begin{array}{c}\text { Land use/ } \\
\text { depth }\end{array}$} & Clay & Silt & Sand & \multirow[t]{2}{*}{ pH } & $\mathbf{K}$ & $\mathrm{Ca}$ & Mg & $\mathbf{P}$ & $\mathrm{Fe}$ \\
\hline & \multicolumn{3}{|c|}{$\mathrm{g} \mathrm{kg}^{-1}$} & & \multicolumn{3}{|c|}{ cmol kg $^{-1}$} & \multicolumn{2}{|c|}{$\mathrm{mg} \mathrm{kg}^{-1}$} \\
\hline \multicolumn{10}{|l|}{$\mathrm{SI}_{\text {pasture }}(\mathrm{N}=6)$} \\
\hline C1 & 352.67 & 323.33 & 270.00 & 8.76 & 1.59 & 15.35 & 3.72 & 8.90 & 15.00 \\
\hline $\mathrm{C} 2$ & 443.33 & 300.00 & 256.67 & 9.06 & 1.00 & 15.53 & 3.35 & 3.50 & 15.00 \\
\hline C3 & 380.33 & 353.33 & 263.33 & 9.03 & 0.48 & 10.01 & 2.44 & 3.50 & 28.80 \\
\hline \multicolumn{10}{|l|}{$\mathrm{SI}_{\text {forest }}(\mathrm{N}=6)$} \\
\hline C1 & 283.33 & 420.00 & 296.67 & 7.54 & 1.19 & 16.32 & 4.93 & 4.20 & 15.00 \\
\hline $\mathrm{C} 2$ & 306.67 & 413.33 & 280,00 & 8.74 & 0.89 & 15.69 & 5.50 & 3.50 & 16.00 \\
\hline $\mathrm{C} 3$ & 330.00 & 423.33 & 246.67 & 8.98 & 0.55 & 15.34 & 5.28 & 6.27 & 16.87 \\
\hline \multicolumn{10}{|l|}{$\mathrm{CN}_{\text {pasture }}(\mathrm{N}=9)$} \\
\hline C1 & 134.89 & 224.44 & 640.67 & 5.31 & 1.00 & 3.99 & 1.82 & 6.50 & 938.34 \\
\hline $\mathrm{C} 2$ & 157.11 & 250.33 & 592.56 & 5.37 & 1.05 & 3.37 & 1.41 & 8.88 & 891.70 \\
\hline $\mathrm{C} 3$ & 129.78 & 237.00 & 633.22 & 5.31 & 0.90 & 2.91 & 1.10 & 4.33 & 761.72 \\
\hline \multicolumn{10}{|l|}{$\mathrm{CN}_{\text {forest }}(\mathrm{N}=6)$} \\
\hline C1 & 197.83 & 198.83 & 603.33 & 5.21 & 0.33 & 4.37 & 1.68 & 3.50 & 557.92 \\
\hline $\mathrm{C} 2$ & 227.83 & 170.00 & 602.17 & 5.19 & 0.25 & 3.57 & 1.43 & 3.50 & 499.24 \\
\hline C3 & 202.33 & 205.50 & 592.17 & 5.27 & 0.30 & 3.30 & 1.33 & 3.73 & 548.82 \\
\hline
\end{tabular}

$\mathrm{CN}_{\text {pasture }}\left(>0.89 \mathrm{cmol} \mathrm{kg}^{-1}\right)$, except in the third layer of $\mathrm{SI}_{\text {forest }}\left(0.55 \mathrm{cmol} \mathrm{kg}^{-1}\right)$, while the values determined in $\mathrm{CN}_{\text {forest }}\left(\right.$ range, $\left.0.25-0.33 \mathrm{cmol} \mathrm{kg}^{-1}\right)$, which were low. The averages of $\mathrm{Ca}$ (pasture, $>10.0 \mathrm{cmol} \mathrm{kg}^{-1}$; forest, $>15.34 \mathrm{cmol} \mathrm{kg}^{-1}$ ) and $\mathrm{Mg}$ (pasture $>2.44 \mathrm{cmol} \mathrm{kg}^{-1}$; forest $>4.93 \mathrm{cmol} \mathrm{kg}^{-1}$ ), were high in all SI soil layers. In the case of $\mathrm{CN}$ soils, $\mathrm{Ca}$ (pasture, $<3.99 \mathrm{cmol} \mathrm{kg}^{-1}$; forest, $<1.82 \mathrm{cmol} \mathrm{kg}^{-1}$ ) and $\mathrm{Mg}$ (pasture, $<4.37 \mathrm{cmol}$ $\mathrm{kg}^{-1}$; forest, $<1.68 \mathrm{cmol} \mathrm{kg}^{-1}$ ), were low and decreased from $\mathrm{C} 1$ to $\mathrm{C} 3$. The P level in all soils was low, and the ranges similar $\left(8.8-3.5 \mathrm{mg} \mathrm{kg}^{-1}\right)$ in the two locations, but with the particularity that the values increased from the upper to the lower layer in the $\mathrm{SI}_{\text {forest }}$ soil from $4.20 \mathrm{mg} \mathrm{kg}^{-1}(\mathrm{C} 1)$ to $6.27 \mathrm{mg} \mathrm{kg}^{-1}(\mathrm{C} 3)$.
Quichimbo et al. (2017) and Jiménez et al. (2007) also found low nutrient levels in pastures and forests, located on high slopes. Priess et al. (2001) indicate that in coastal and mountain grazing soils of Ecuador, nutrient losses are not compensated for by livestock manure input. On the other hand, the quality and quantity of biomass generated by pastures and forests are linked to the quantities of nutrients, which are reduced by factors such as the topography of the terrain (high slope), the quantity of clay and the climate conditions (high precipitation) (Marconi et al. 2018). 
The mineral Fe was low $\left(\leq 28.80 \mathrm{mg} \mathrm{kg}^{-1}\right.$ ) for SI soils and high in $\mathrm{CN}$, mainly in $\mathrm{CN}_{\text {pasture }}$, with values that decreased from $\mathrm{C} 1\left(938.34 \mathrm{mg} \mathrm{kg}^{-1}\right)$ to C3 (761.72 $\mathrm{mg} \mathrm{kg}^{-1}$ ), followed by $\mathrm{CN}_{\text {forest }}$ soil in C1 (557.92mg kg-1). Fe levels that are associated with the acidic $\mathrm{pH}$ reaction (Makeschin et al., 2008), and a lower meteorization of the soils in mountain areas concerning to the soils of the Ecuadorian coast (García-Cruzatty et al., 2012).

The Tukey test, for total flora, indicates statistical insignificance $(\mathrm{p}<0,05)$ among the land uses (Table $3)$. The highest average corresponded to $\mathrm{CN}_{\text {pasture }}$ $\left(8.5 \times 10^{6} \mathrm{CFU} \mathrm{g}^{-1}\right)$. High total flora value concerning Álvarez-Solís and Azueto-Martínez (2004) research, which showed values between 6.27 $6.91 \times 10^{6} \mathrm{CFU} \mathrm{g}^{-1}$ in the grass and native forest with soil properties similar to the study (pH: 4.40 - 5.1 with sandy loam texture). In the case of SI ${ }_{\text {pasture }}$ soils, the total flora count was low compared to the average of $4.1 \times 10^{6} \mathrm{CFU} \mathrm{g}^{-1}$, obtained in soybeans in clay loam soils and $\mathrm{pH}=6.01-6.4$ (Fernández et al., 2005). In investigations on microbial activity in Ecuadorian soils, a direct relationship with OC and mainly between $\mathrm{P}$ and the abundance of grampositive bacteria was determined (Crespo et al., 2011; Potthast et al., 2012; Tischer et al., 2014). In the investigation, $\mathrm{SI}_{\text {forest }}$ and $\mathrm{CN}_{\text {forest }}$ soils showed the lowest levels of $\mathrm{P}$ (Table 2); therefore, a low incidence of the bacterial total flora.

The four averages of colimetry (Table 3), a soil biological indicator related to the number of bacteria in the fecal matter, did not show significant differences ( $p$-value $=0.28)$. The colimetry values ranged from $1.95 \times 10^{6}\left(\mathrm{CN}_{\text {pasture }}\right)$ to $0.39 \times 10^{6}\left(\mathrm{SI}_{\text {pasture }}\right)$. For Chen et al. (2018), high bacterial loads in the soil are related to acid $\mathrm{pH}$, while Weil and Brady (2017) express, that anthropogenic disturbances are generally more accentuated in soils with an alkaline $\mathrm{pH}$, is a negative factor for the increase of microbial activity. Fernández et al. (2005) pointed out that the amount of CFU g-1 of colimetry is related to soil management, such as the excessive application of chemical fertilizers and pesticides, which decreases the levels of colimetry, while the use of organic fertilizers increases this biological indicator.

Table 3. Tukey test $(\mathrm{P}<0.05)$ between colony-forming units $(\mathrm{CFU})$ of total flora $(\mathrm{TF})$ and colimetry $(\mathrm{CL})$ of bacteria by soil use, between zero and $10 \mathrm{~cm}$.

\begin{tabular}{|c|c|c|c|c|c|c|c|c|}
\hline \multirow{2}{*}{$\begin{array}{l}\text { Land use } \\
(\mathrm{N}=3)\end{array}$} & \multicolumn{4}{|c|}{ FT (CFU grams of soil) } & \multicolumn{4}{|c|}{ CL (CFU grams of soil) } \\
\hline & average & SE & Range & $\begin{array}{c}\text { Sig. } \\
(\mathrm{p}<0,05)\end{array}$ & average & SE & Range & $\begin{array}{c}\text { Sig. } \\
(p<0,05)\end{array}$ \\
\hline \multicolumn{9}{|l|}{$S I_{\text {pasture }}$} \\
\hline & $3,23 \times 10^{6} \mathrm{ab}$ & $1,19 \times 10^{6}$ & $3,90 \times 10^{6}$ & & $0,39 \times 10^{6} \mathrm{a}$ & $0,28 \times 10^{6}$ & $8,70 \times 10^{5}$ & \\
\hline \multicolumn{9}{|l|}{$\mathrm{SI}_{\text {forest }}$} \\
\hline $\mathrm{CN}_{\text {pasture }}$ & $3,60 \times 10^{6} \mathrm{a}$ & $0,10 \times 10^{6}$ & $3,20 \times 10^{5}$ & 0,01 & $1,45 \times 10^{6} \mathrm{a}$ & $0,47 \times 10^{6}$ & $1,56 \times 10^{6}$ & 0,28 \\
\hline & $8,50 \times 10^{6} \mathrm{a}$ & $0,20 \times 10^{6}$ & $6,10 \times 10^{6}$ & & $1,95 \times 10^{6} \mathrm{a}$ & $1,03 \times 106$ & $3,42 \times 10^{6}$ & \\
\hline \multicolumn{9}{|l|}{$\mathrm{CN}_{\text {forest }}$} \\
\hline & $1,46 \times 106 \mathrm{~b}$ & $0,77 \times 106$ & $2,50 \times 10^{6}$ & & $0,60 \times 106 a$ & $0,17 \times 106$ & 560000 & \\
\hline
\end{tabular}

$E E=$ standard error of the average, Sig= significance $(p$-valor $<0,05)$ 
Another factor that can influence the flora total and colimetry values is the root development of the pasture, which presents a greater accumulation of roots in the first $10 \mathrm{~cm}$ of the soil, and therefore a greater number of bacteria (Makeschin et al., 2008).

The values of $\mathrm{Bd}$ presented in Table 4, show significance $(p<0,05)$, in the use of forest land, which indicated ranges of $1,04 \mathrm{Mg} \mathrm{m}^{3}-1.13 \mathrm{Mg}$ $\mathrm{m}^{3}$. Significance $(\mathrm{p}<0,05)$ in $0 \mathrm{C}$ was also observed in SI soils and CNforest. Therefore, the depth of sampling had an influence on the variability of BD only in SI. In CNforest, average Bd decreased from $1,24 \mathrm{Mg} \mathrm{m}^{3}$ to $1,12 \mathrm{Mg} \mathrm{m}^{3}$ between $\mathrm{C} 1$ and $\mathrm{C} 3$, respectively. In pastureland uses, an increase in Da from C1 to C3 was observed ( $\mathrm{SI}_{\text {pasture }} 1,09-1,13 \mathrm{Mg}$ $\mathrm{m}^{3} ; \mathrm{CN}_{\text {pasture }} 1,04-1,11 \mathrm{Mg} \mathrm{\textrm {m } ^ { 3 }}$ ). Values that in general do not indicate soil compaction problems $\left(>1,6 \mathrm{Mg} \mathrm{m}^{3}\right)$ and are within the range $(1,1-1,2 \mathrm{Mg}$ $\mathrm{m}^{3}$ ) of fine-textured soils such as loam, clay loam and the range $\left(1,2-1,6 \mathrm{Mg} \mathrm{m}^{3}\right)$ of coarse-textured soils (sandy loam), as indicated by Salamanca and Khalajabadi (2005) and Brahma et al. (2018). This revealed that the root development of the grass was not affected. Six et al. (1998) and De Blécourt et al. (2017) found a direct relationship between the values of $\mathrm{Bd}$ that increased from 0,84 to $1,18 \mathrm{Mg}$ $\mathrm{m}^{3}$ between zero and $30 \mathrm{~cm}$, while $0 \mathrm{C}$ decreased on average, as the values obtained in this research.

Table 4. ANOVA and Tukey test $(\mathrm{P}<0.05)$ for Bulk Density $(\mathrm{Bd})$ and Organic Carbon (OC), by land use.

\begin{tabular}{|c|c|c|c|c|c|c|c|c|}
\hline \multirow[b]{2}{*}{ Land Use } & \multicolumn{4}{|c|}{$\mathrm{Bd}\left(\mathrm{Mg} \mathrm{m}^{3}\right)$} & \multicolumn{4}{|c|}{ OC $\left(\mathrm{g} \mathrm{kg}^{-1}\right)$} \\
\hline & Average & SE & Range & $\begin{array}{c}\text { Sig. } \\
(\mathrm{P}<0,05)\end{array}$ & Average & SE & Range & $\begin{array}{c}\text { Sig. } \\
\text { (p-valor }<0,05)\end{array}$ \\
\hline \multicolumn{9}{|l|}{$\mathrm{SI}_{\text {pasture }}(\mathrm{N}=6)$} \\
\hline $\mathrm{C} 1$ & $1,09 \mathrm{sn}$ & 0,02 & 0,13 & 0,34 & $16,8 \mathrm{a}$ & 1,29 & 6,65 & 0,00 \\
\hline $\mathrm{C} 2$ & $1,10 \mathrm{sn}$ & 0,02 & 0,16 & & $11,13 \mathrm{~b}$ & 1,16 & 5,95 & \\
\hline $\mathrm{C} 3$ & $1,13 \mathrm{sn}$ & 0,01 & 0,08 & & $6,73 \mathrm{~b}$ & 1,99 & 5,47 & \\
\hline \multicolumn{9}{|l|}{$\mathrm{SI}_{\text {forest }}(\mathrm{N}=6)$} \\
\hline $\mathrm{C} 1$ & $1,04 a$ & 0,02 & 0,13 & 0,01 & 35,45 a & 9,36 & 47,60 & 0,00 \\
\hline $\mathrm{C} 2$ & $1,13 b$ & 0,02 & 0,14 & & $9,53 \mathrm{~b}$ & 3,67 & 24,60 & \\
\hline $\mathrm{C} 3$ & $1,12 \mathrm{~b}$ & 0,02 & 0,12 & & $3,58 \mathrm{~b}$ & 1,52 & 10,00 & \\
\hline \multicolumn{9}{|l|}{$\mathrm{CN}_{\text {pasture }}(\mathrm{N}=9)$} \\
\hline $\mathrm{C} 1$ & $1,04 \mathrm{sn}$ & 0,05 & 0,40 & 0,76 & $30,81 \mathrm{sn}$ & 2,83 & 13,05 & 0,87 \\
\hline $\mathrm{C} 2$ & $1,06 \mathrm{sn}$ & 0,07 & 0,55 & & $32,86 \mathrm{sn}$ & 3,52 & 16,21 & \\
\hline $\mathrm{C} 3$ & $1,11 \mathrm{sn}$ & 0,09 & 0,70 & & $33,71 \mathrm{sn}$ & 5,11 & 23,58 & \\
\hline \multicolumn{9}{|l|}{$\mathrm{CN}_{\text {forest }}(\mathrm{N}=6)$} \\
\hline $\mathrm{C} 1$ & $1,24 \mathrm{sn}$ & 0,04 & 0,32 & 0,13 & $22,50 \mathrm{~b}$ & 1,69 & 18,39 & 0,01 \\
\hline $\mathrm{C} 2$ & $1,21 \mathrm{sn}$ & 0,02 & 0,12 & & $19,12 \mathrm{~b}$ & 1,16 & 14,82 & \\
\hline $\mathrm{C} 3$ & $1,12 \mathrm{sn}$ & 0,05 & 0,33 & & $29,72 \mathrm{a}$ & 2,63 & 21,70 & \\
\hline
\end{tabular}

$\mathrm{EE}=$ standard error of the mean, Sig = significance $(\mathrm{p}$-value $<0.05)$ Different letters indicate statistical significance. 
The levels of OC (Table 4), in SI soils, did not decrease homogeneously as can be seen in the ranges of $\mathrm{SI}_{\text {pasture }}$ between $16.8-6.73 \mathrm{~g} \mathrm{~kg}^{-1}$ and $35.45-3.58 \mathrm{~g} \mathrm{k}^{-1}$ in $\mathrm{SI}_{\text {forest }}$. The result indicated a significant $(\mathrm{p}<0,01)$ between $\mathrm{C} 1$ and the rest of the depths. The heterogeneity in the distribution and age of the dispersed trees, the shrub vegetation in the grass and the forest species in the forest, guaranteed a constant input of $\mathrm{OC}$, but also rapid mineralization of carbon in the first layer (Wilcke et al., 2002); which did not allow the eluviation of OC to the depths C2 and C3. At $\mathrm{CN}_{\text {pasture' }}$ OC levels were more homogeneous and ranged from 30.81 to $33.71 \mathrm{~g} \mathrm{~kg}^{-1}$, showing no significance $(\mathrm{p}<0.05)$. The $\mathrm{CN}_{\text {pasto }}$ land use showed, OC levels ranging from 22.50 to $29.72 \mathrm{~g} \mathrm{k}^{-1}$, and significance ( $\mathrm{p}<0.05$ ) of depth three with $\mathrm{C} 1$ and $\mathrm{C} 2$. The ranges of $\mathrm{OC}$, determined in the study were different from those obtained by Rhoades et al. (2000) from 20.22 to $48.20 \mathrm{~g} \mathrm{~kg}^{-1}$ in pasture and 21.70 to $48.2 \mathrm{~g} \mathrm{~kg}^{-1}$ in the forest at $<1000 \mathrm{~m}$ altitude, on soils of sedimentary origin.

In Figure 2A, only the stored SOC values showed significant differences ( $p$-value $<0.05)$ in SI soils. The highest average SOC stored in the SI site were: $\mathrm{SI}_{\text {forest }}(\mathrm{C} 1,36.30 \mathrm{Mg} \mathrm{C} \mathrm{ha-1}), \mathrm{SI}_{\text {pasture }}(\mathrm{C} 1,18.43 \mathrm{Mg}$ C ha-1), $\mathrm{SI}_{\text {pasture }}\left(\mathrm{C} 2,12.27 \mathrm{Mg} \mathrm{C} \mathrm{ha-1)}, \mathrm{SI}_{\text {forest }}(\mathrm{C} 2\right.$, $\left.12.27 \mathrm{Mg} \mathrm{C} \mathrm{ha}^{-1}\right)$. In the rest of the layers, the values of SOC wired were $57.67 \mathrm{Mg}$ of $\mathrm{C} \mathrm{ha}^{-1}$. In the CN soils, the averages were more adjusted, with the particularity that the highest values of SOC stored $\left(\mathrm{CN}_{\text {pasture' }}, 35.01 \mathrm{Mg} \mathrm{C} \mathrm{ha-1} ; \mathrm{CN}_{\text {forest }} 33.24 \mathrm{Mg}\right.$ $\mathrm{C} \mathrm{ha-1}$ ), were seen in the last depth. These levels are below those determined by McGroddy et al. (2015), in a silvopastoral system in the southwestern Andes in Ecuador, who mentions a maximum value of $40.8 \mathrm{Mg} \mathrm{C}$ ha $^{-1}$ and are less than $45.55 \mathrm{Mg}$ $\mathrm{C} \mathrm{ha}^{-1}$ in cocoa plantations, as indicated by Barrezueta-Unda et al. (2018), in the area under study. OC inputs from the biomass generated by forests over 40 years old, are between 104 and $158 \mathrm{Mg}$ C ha $^{-1}$, much higher than the results reported in the study, but are over the range of 2 to $18 \mathrm{Mg} \mathrm{C} \mathrm{ha}^{-1}$ of biomass generated by pastures in the mountains of the Buenaventura reserve (El Oro province) (Spracklen and Righelato, 2016).

The comparison in percentages of the stored SOC (Figure 2B), indicated significance ( $p$-value $<0.05$ ) in the land uses $\mathrm{SI}_{\text {pasture' }} \mathrm{SI}_{\text {forest' }}$ and $\mathrm{CN}_{\text {forest }}$ ' In the SI soils, the first $10 \mathrm{~cm}$ accumulated the highest percentage of SOC with $71.10 \%$, in $\left(\mathrm{SI}_{\text {forest }}\right)$ and $48.03 \%\left(\mathrm{SI}_{\text {pasture }}\right.$ ), while in $\mathrm{CN}_{\text {pasture }}$ the percentages were $31.48,33.48$ and $35.06 \%$ for C1, C2 and C3 respectively. In $\mathrm{CN}_{\text {forest }}$ the percentage distribution of stored SOC was 32.93, 27.47 and $39.60 \%$ for $\mathrm{C} 1, \mathrm{C} 2$, and C3, in that order. These results are consistent with other research on high slope soils, where more than $60 \%$ of stored soc is located in the first $0.20 \mathrm{~m}$ of the soil (Tonucci et al., 2017; Gebeyehu and Soromessa, 2018). The homogeneous distribution of the SOC in steeply sloping terrain is related to several factors such as the previous plant composition and the degree of profile formation, runoff, etc., while in flat areas the accumulation of $O C$ is greater in the first $10 \mathrm{~cm}$ as a result of the accumulation of biomass, which produces the formation of deeper humic horizons (Barré et al., 2017).

The Pearson correlation analysis (Table 5), between SOC stored by land use and $\mathrm{pH}, \mathrm{P}, \mathrm{K}, \mathrm{Ca}, \mathrm{Mg}$ and $\mathrm{Fe}$ properties, indicated a negative association at $5 \%$ significance with $\mathrm{pH}$ in SIpasture $\left(\mathrm{r}=-0.57^{*}\right)$ and SIforest $\left(\mathrm{r}=-0.48^{*}\right)$ land uses, revealing that the acidic condition of the soil negatively influences COS levels, as also found by Miretti et al. (2012) in grasslands of Santa Fe province, Argentina. While a positive correlation with $\mathrm{Fe}$ is shown in the $\mathrm{CN}_{\text {forest }}$ soil $\left(\mathrm{r}=0,55^{*}\right)$ and a high positive correlation with $\mathrm{K}\left(1 \%\right.$ of significance) in the $\mathrm{SI}_{\text {forest }}$ soil $\left(\mathrm{r}=0,83^{* *}\right)$, similar relationships were described by Beltran et al. (2016) in loamy soil texture cultivated with vines in La Rioja, Spain, while Peregrina et al. (2010) found a negative correlation in soils with alpha-maizesorghum rotation in Argentina. 
40,00

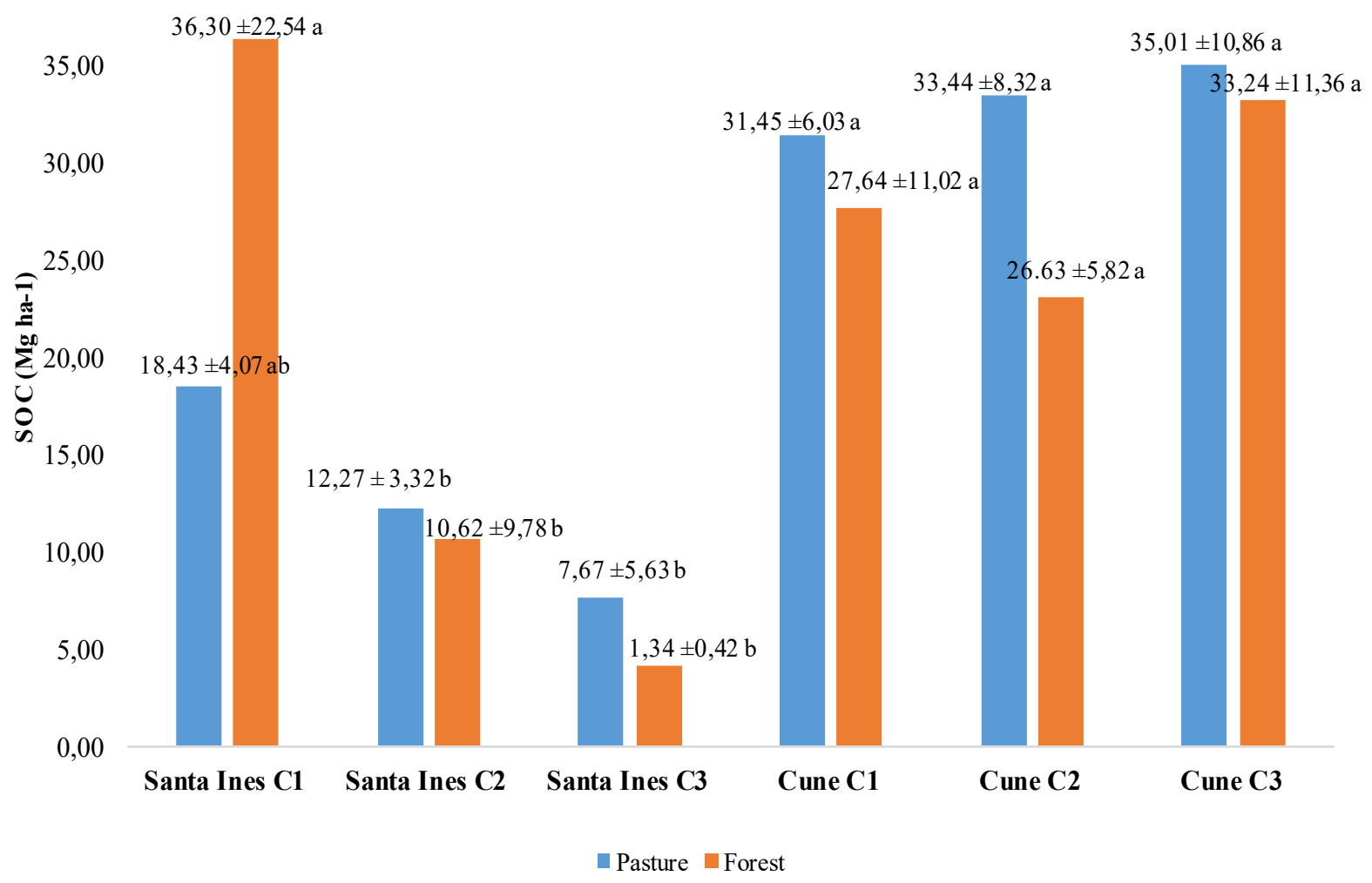

B

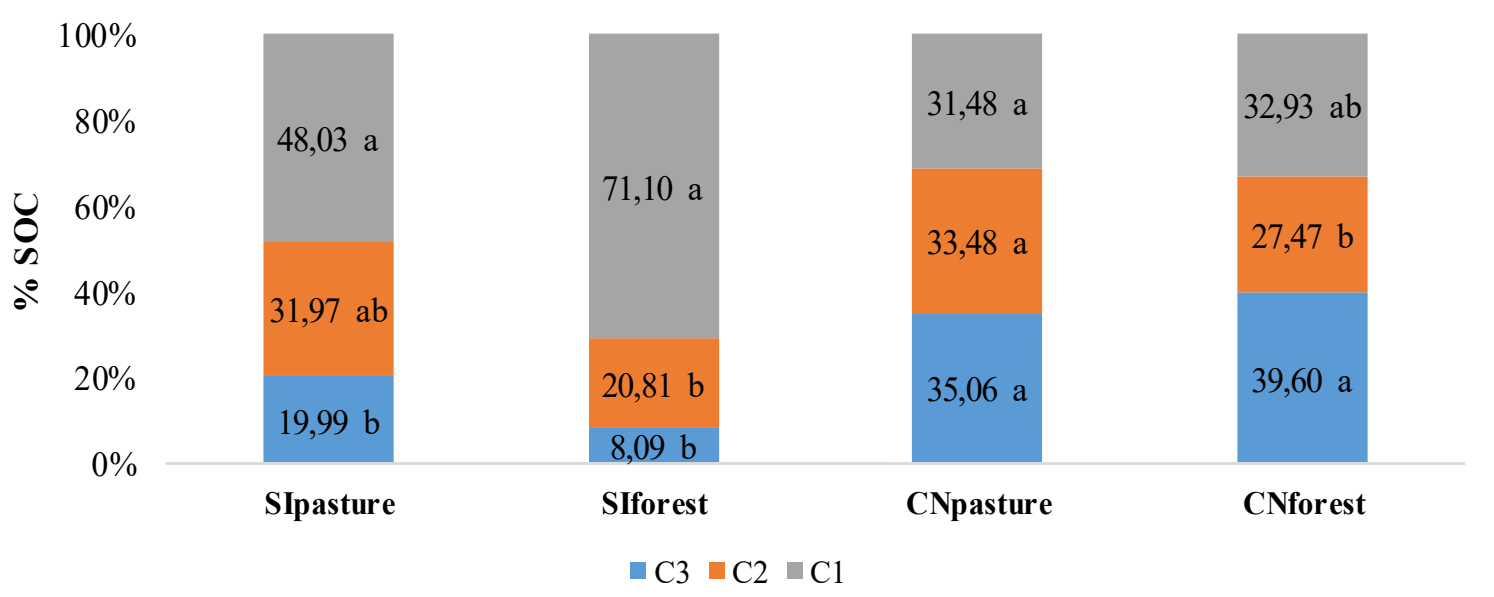

Figure 2. Tukey test applied to: A) Comparison of SOC by layer for each land use, B) Distribution of SOC by land use. 
Table 5. Pearson's correlation matrix between stored SOC by land use and physical and chemical properties.

\begin{tabular}{lcccc}
\hline & $\mathrm{SI}_{\text {pasture }} \mathrm{SOC}$ & $\mathrm{SI}_{\text {forest }} \mathrm{SOC}$ & $\mathrm{CN}_{\text {pasture }} \mathrm{SOC}$ & $\mathrm{CN}_{\text {forest }} \mathrm{SOC}$ \\
\hline $\mathrm{pH}$ & $-0.57^{*}$ & $-0.48^{*}$ & 0.17 & -0.10 \\
$\mathrm{P}$ & 0.13 & -0.30 & 0.08 & -0.22 \\
$\mathrm{~K}$ & 0.43 & $0.83^{* *}$ & 0.07 & -0.04 \\
$\mathrm{Ca}$ & 0.16 & -0.01 & -0.08 & -0.16 \\
$\mathrm{Mg}$ & 0.55 & -0.07 & -0.14 & -0.02 \\
$\mathrm{Fe}$ & -0.03 & 0.24 & 0.51 & $0.55^{*}$ \\
\hline
\end{tabular}

\section{CONCLUSIONS}

The land uses showed very marked differences between physical (clay, sand, and Bd) and chemical ( $\mathrm{pH}$ and Fe) properties per site; soil formation being one of the factors of its differentiation. In the case of the biological properties total flora and colimetry, the results were similar among the soils accepted in the pasture of the Cune site, which showed much higher CFU values, due to the acidity of the soil and a higher amount of $\mathrm{P}$, factors that facilitate the growth of bacterial colonies.

On the other hand, the OC values were very homogeneous in the three depths of both the pasture and the forest in the Cune site, while in the soils of Santa Inés the OC levels decreased as the sampling deepened. This difference may be related to the elution phenomenon due to the predominance of the sand fraction and the slope at the Cune site.

The amount of SOC stored in the forest land use was lower than other investigations carried out in conditions of slope and climate equal to the study. But the values determined for SOC in the pasture were similar to other investigations. Therefore, it is concluded that changes in SOC storage by layers are more pronounced in SI than in CN.

Conflict of interest: The authors declare that there is no conflict of interest.

\section{BIBLIOGRAPHIC REFERENCES}

Álvarez-Solís, J.; Anzueto-Martínez, M. (2004). Actividad microbiana del suelo bajo diferentes sistemas de producción de maíz en los altos de Chiapas, México. Agrociencia. 38(1):13-22.

Baldock, J. (1982). Geología del Ecuador: Boletín de Explicación del Mapa geológico de la República del Ecuador. (IGM, Ed.). Quito: Dirección General de Geología y Minas.

Barré, P.; Durand, H.; Chenu, C.; Meunier, P.; Montagne, D.; Castel, G.; Billioub, D.; Soucémarianadin, L.; Cécillon, L. (2017). Geological control of soil organic carbon and nitrogen stocks at the landscape scale. Geoderma. 285(January): 50-56. doi: https://doi. org/10.1016/j.geoderma.2016.09.029

Barrezueta-Unda, S.; Luna-Romero, A.; Barrera-León, J. (2018). Almacenamiento de carbono en varios suelos cultivados con cacao en la provincia El OroEcuador. Revista Agroecosistem. 6(1): 154-161.

Beltran, M.J.; Brutti, L.; Romaniuk, R.; Bacigaluppo, S.; Salvagiotti, F.; Sainz-Rozas, H.; Galantini, J.A. (2016). Calidad de la materia orgánica y disponibilidad de macro y micronutrientes por la inclusión de trigo como cultivo de cobertura. Ciencia del Suelo. 34(1): 67-79.

Blake, G.R. (1965). Bulk density. In: Black, C. A. (Ed.), Methods of Soil Analysis: Part 1 Physical and Mineralogical Properties, Including Statistics of Measurement and Sampling. pp. 374-390. Saint Paul: American Society of Agronomy. doi: https:// doi.org/10.2134/agronmonogr9.1.c30 
Brahma, B.; Pathak, K.; Lal, R.; Kurmi, B.; Das, M.; Nath, P.C.; Nath, A.J.; Das, A.K. (2018). Ecosystem carbon sequestration through restoration of degraded lands in Northeast India. Land Degradation $y$ Development. 29(1): 15-25. doi: https://doi. org/10.1002/ldr.2816

Bravo, C.; Ramírez, A.; Marín, H.; Torres, B.; Alemán, R.; Torres, R.; Navarrete, H.; Changoluisa, D. (2017). Factores asociados a la fertilidad del suelo en diferentes usos de la tierra de la Región Amazónica Ecuatoriana. Revista Electronica de Veterinaria. 18(11): 1-6.

Chen, S.; Arrouays, D.; Angers, D.; Martin, M.; Walter, C. (2019). Soil carbon stocks under different land uses and the applicability of the soil carbon saturation concept. Soil and Tillage Research. 188: 53-58. doi: https://doi.org/10.1016/j.still.2018.11.001

Chen, S.; Wang, W.; Xu, W.; Wang, Y.; Wan, H.; Chen, D.; Tang, Z.; Tang, X.; Zhou, G.; Xie, Z.; Zhou, D.; Shangguan, Z.; Huanga, J.; He, J.; Wang, Y.; Sheng, J.; Tang, L.; Li, X.; Dong, M.; Wu, Y.; Wang, Q.; Wang, Z.; Wu, J.; Chapin III, S.; Bai, Y. (2018). Plant diversity enhances productivity and soil carbon storage. Proceedings of the National Academy of Sciences. 115(16): 4027-4032. doi: https://doi.org/10.1073/ pnas. 1700298114

Crespo, P.; Feyen, J.; Buytaert, W.; Bücker, A.; Breuer, L. (2011). Identifying controls of the rainfall - runoff response of small catchments in the tropical Andes (Ecuador). Journal of Hydrology. 407(1-4): 164-174. doi: https://doi.org/10.1016/j.jhydrol.2011.07.021

De Blécourt, M.; Corre, M.D.; Paudel, E.; Harrison, R.D.; Brumme, R.; Veldkamp, E. (2017). Spatial variability in soil organic carbon in a tropical montane landscape: associations between soil organic carbon and land use, soil properties, vegetation, and topography vary across plot to landscape scales. SOIL. 3(3): 123-137. doi: https://doi.org/10.5194/ soil-3-123-2017

De Koning, G.H.J.; Veldkamp, E.; López-Ulloa, M. (2003). Quantification of carbon sequestration in soils following pasture to forest conversion in northwestern Ecuador. Global Biogeochemical Cycles. 17(4): 1098. doi: https://doi.org/10.1029/2003GB002099
Don, A., Schumacher, J. \& Freibauer, A. (2011). Impact of tropical land-use change on soil organic carbon stocks - a meta-analysis. Global Change Biology. 17(4): 1658-1670. doi: https://doi.org/10.1111/ j.1365-2486.2010.02336.x

FAO - Organización de las Naciones Unidas para la Alimentación y la Agricultura. (2014). Informe nacional: Ecuador. Evaluación de los recursos forestales mundiales 2015. Ecuador: FA0.

FAO - Organización de las Naciones Unidas para la Alimentación y la Agricultura. (2017). Soil organic carbon: The hidden potential. Roma, Italy: Food and Agriculture Organization of the United Nations. doi: https://doi.org/10.1038/nrg2350

Fernández, L.; Zalba, P.; Gómez, M.; Sagardoy, M. (2005). Bacterias solubilizadoras de fosfato inorgámico aisladas de suelos de la region sojera. Ciencia del Suelo. 23(1): 31-37.

García-Cruzatty, L.; Schlatter-Vollmann, J. (2012). Caracterización de suelos a lo largo de un gradiente altitudinal en Ecuador. Revista Brasileira de Ciências Agrárias. 7(3): 456-464. doi: https://doi. org/10.5039/agraria.v7i3a1736

Gebeyehu, G.; Soromessa, T. (2018). Status of soil organic carbon and nitrogen stocks in Koga Watershed Area, Northwest Ethiopia. Agriculture y Food Security. 7(1): 1-10. doi: https://doi.org/10.1186/s40066018-0162-8

Hamer, U.; Potthast, K.; Burneo, J.I.; Makeschin, F. (2013). Nutrient stocks and phosphorus fractions in mountain soils of Southern Ecuador after conversion of forest to pasture. Biogeochemistry. 112(1-3): 495-510. doi: https://doi.org/10.1007/ s10533-012-9742-z

Horstman, E.; Ayón, J.; Griscom, H. (2018). Growth, survival, carbon rates for some dry tropical forest trees used in enrichment planting in the Cerro Blanco protected forest on the Ecuadorian coast. Journal of Sustainable Forestry. 37(2): 82-96. doi: https://doi.org/10.1080/10549811.2017.1387153

INEC - Instituto Nacional de Estadística y Censos. (2011). Reporte Estadístico el Sector Agropecuario. Ecuador: INEC. 
Jiménez, J.J.; Lal, R. (2006). Mechanisms of C Sequestration in Soils of Latin America. Critical Reviews in Plant Sciences. 25(4): 337-365. doi: https://doi.org/10.1080/0735268060094240

Jiménez,L.S.; Mezquida, E.T.; Benito, M.; Rubio, A. (2007). Transformación de áreas boscosas en pastizales en Zamora-Chinchipe (Ecuador). Sociedad Española de Ciencias Forestales. 70: 65-70.

Lal, R. (2015). Restoring Soil Quality to Mitigate Soil Degradation. Sustainability. 7(5): 5875-5895. doi: https://doi.org/10.3390/su7055875

Lefèvre, C.; Rekik, F.; Alcantara, V.; Wiese, L. (2017). Soil organic carbon: The hidden potential. Rome, Italy: Food and Agriculture Organization of the United Nations.

Liang, X.; Erickson, J.E.; Silveira, M.L.; Sollenberger, L.E.; Rowland, D.L. (2016). Tissue chemistry and morphology affect root decomposition of perennial bioenergy grasses on sandy soil in a sub-tropical environment. Bioenergy. 8(5): 1015-1024. doi: https://doi.org/10.1111/gcbb.12315

Liang, X.; Erickson, J.E.; Silveira, M.L.; Sollenberger, L.E.; Rowland, D.L.; Vermerris, W. (2019). Quantifying shoot and root biomass production and soil carbon under perennial bioenergy grasses in a subtropical environment. Biomass and Bioenergy. 128: 105323. doi: https://doi.org/10.1016/j. biombioe.2019.105323

Lorenz, K.; Lal, R. (2018). Carbon Sequestration in Agricultural Ecosystems. Cham: Springer International Publishing. doi: https://doi. org/10.1007/978-3-319-92318-5

Luna-Romero, A.; Ramírez, I.; Sánchez, C.; Conde, J.; Agurto, L.; Villaseñor, D. (2018). Spatio-temporal distribution of precipitation in the Jubones river basin, Ecuador: 1975-2013. Scientia Agropecuaria. 9(1): 63-70. doi: https://doi.org/10.17268/sci. agropecu.2018.01.07

MAE - Ministerio del Ambiente de Ecuador. (2015). Estadísticas de Patrimonio Natural: Datos de bosque, ecosistemas, especies, carbono y deforestación del Ecuador continental. Recovered from http://www. fao.org/forestry/44292-07669536a0752fc4ce8e9 d3066b05a109.pdf

Makeschin, F.; Haubrich, M.; Abiy, M.; Burneo, J.; Klinger, T. (2008). Pasture Management and Natural Soil. In: E. Beck (Ed.), Gradients in a Tropical Mountain Ecosystem of Ecuador. pp. 397 - 408. Berlin: Springer International Publishing.

Marconi, R.; Erraez, M.; Manosalva, C.V. (2018). Impacto de la fertilización mineral y enmiendas sobre Gmelina arborea y Schizolobium parahyba en suelos andesíticos de la Amazonía Ecuatoriana Impact of mineral fertilization and amendments on Gmelina arborea and. Revista Centro Agrícola. 45(4): 49-58.

McGroddy, M.E.; Lerner, A.M.; Burbano, D.V.; Schneider, L.C.; Rudel, T.K. (2015). Carbon Stocks in Silvopastoral Systems: A Study from Four Communities in Southeastern Ecuador. Biotropica. 47(4): 407 - 415. doi: https://doi.org/10.1111/ btp.12225

Meyer, R.S.; Cullen, B.R.; Whetton, P.H.; Robertson, F.A.; Eckard, R.J. (2018). Potential impacts of climate change on soil organic carbon and productivity in pastures of southeastern Australia. Agricultural Systems. 167:34 - 46. doi: https://doi.org/10.1016/j. agsy.2018.08.010

Monroe, P.H.M.; Gama-Rodrigues, E.F.; Gama-Rodrigues, A.C.; Marques, J.R.B. (2016). Soil carbon stocks and origin under different cacao agroforestry systems in Southern Bahia, Brazil. Agriculture, Ecosystems y Environment. 221(1): 99-108. doi: https://doi. org/10.1016/j.agee.2016.01.022

Miretti, M. C., Pilatti, I., Lavado, R. S.; Imhoff, S. D. C. (2012). Historia de uso del suelo y contenido de micronutrientes en Argiudoles del centro de la provincia de Santa Fe (Argentina). Ciencia Del Suelo. 30(1): 67-73.

Moreno, J.; Sevillano, G.; Valverde, 0.; Loayza, V.; Haro, R.; Zambrano, J. (2016). Soil from the Coastal Plane. In: Espinosa, J., Moreno, J. \& Bernal, G. (Eds.). The Soils of Ecuador. pp. 1-195. Cham, Switzerland: Springer International Publishing. doi: https://doi. org/10.1007/978-3-319-20541-0

Munsell Color. (1994). Munsell soil color charts. New Windsor, NY: Kollmorgen Instruments Corporation. 
Novara, A.; Minacapilli, M.; Santoro, A.; Rodrigocomino, J.; Carrubba, A. (2018). Real cover crops contribution to soil organic carbon sequestration in sloping vineyard. Science of the Total Environment. 652: 300-306. doi: https://doi.org/10.1016/j. scitotenv.2018.10.247

Olsen, S.; Sommers, L. (1982). Phosphorous. In: Page, A. L. (ed.). Methods of soil analysis part 2, chemical, and microbiological properties. pp. 403-430. Madison: American Society of Agronomy, Soil Science Society of America, Inc.

Ortíz-Maya, J.; Escalante-Espinosa, E.; FócilMonterrubio, R.L.; Ramírez-Saad, H.C.; Díaz, I.J. (2017). Dinámica de poblaciones bacterianas y actividad deshidrogenasa durante la biorremediación de suelo recién contaminado e intemperizado con hidrocarburos. Revista Internacional de Contaminacion Ambiental. 33(2): 237-246. doi: https://doi.org/10.20937/ RICA.2017.33.02.05

Peregrina, F.; López, D.; Zaballa, 0.; Villar, M.T.; González, G. (2010). Calidad de los suelos de viñedo en la Denominación de Origen Rioja: Índice de riesgo de encostramiento (FAOPNUMA), contenido de carbono orgánico y relación con la fertilidad del suelo. Revista de Ciências Agrárias. 33(1): 338-345

Potthast, K.; Hamer, U.; Makeschin, F. (2012). Land-use change in a tropical mountain rainforest region of southern Ecuador affects soil microorganisms and nutrient cycling. Biogeochemistry. 111(1-3): 151167. doi: https://doi.org/10.1007/s10533-0119626-7

Priess, J.; De Koning, G.H.; Veldkamp, A. (2001). Assessment of interactions between land-use change and carbon and nutrient fluxes in Ecuador. Agriculture, Ecosystems y Environment. 85(1-3): 269-279. doi: https://doi.org/10.1016/S01678809(01)00193-1

Quichimbo, P.; Tenorio, G.; Borja, P.; Cárdenas, I.; Crespo, P.; Célleri, R. (2017). Efectos sobre las propiedades físicas y químicas de los suelos por el cambio de la cobertura vegetal y uso del suelo: páramo de Quimsacocha al sur del Ecuador. Suelos Ecuatoriales. 42(2): 138-153.
Rees, R. M.; Bingham, I.J.; Baddeley, J.A.; Watson, C.A. (2005). The role of plants and land management in sequestering soil carbon in temperate arable and grassland ecosystems. Geoderma. 128(12): 130-154. doi: https://doi.org/10.1016/j. geoderma.2004.12.020

Reyna-Bowen, L.; Vera-Montenegro, L.; Reyna, L. (2019). Soil organic carbon concentration and storage under different land uses in the CarrizalChone. Applied Sciences. 9(45): 1-9. https://doi. org/10.3390/app9010045

Rhoades, C.C.; Eckert, G.E.; Coleman, D.C. (2000). Soil carbon differences among forest, agriculture, and secondary vegetation in lower montane Ecuador. EcologicalApplications. 10(2): 497-505. doi: https:// doi.org/10.1890/1051-0761(2000)010[0497:SCD AFA]2.0.CO;2

Salamanca, A.; Khalajabadi, S. (2005). La densidad aparente y su relación con otras propiedades en suelos de la zona cafetera colombiana. Cenicafé. 56(4): 381-397.

Six, J.; Elliott, E.; Paustian, K.; Doran, J. W. (1998). Aggregation and soil organic matter accumulation in cultivated and native grassland soils. Soil Science Society of America Journal. 62: 1367-1377. doi: https://doi.org/10.2136/ sssaj1998.03615995006200050032x

Spracklen, D.V.; Righelato, R. (2016). Carbon storage and sequestration of re-growing montane forests in southern Ecuador. Forest Ecology and Management. 364: 139-144. doi: https://doi.org/10.1016/j. foreco.2016.01.001

SPSS - Statistical Package for the Social Sciences. (2013). SPSS Statistics for Windows. Chicago, IL, USA: IBM Corp.

Takoutsing, B.; Weber, J.C.; Tchoundjeu, Z.; Shepherd, K. (2016). Soil chemical properties dynamics as affected by land-use change in the humid forest zone of Cameroon. Agroforestry Systems. 90(6): 1089-1102. doi: https://doi.org/10.1007/s10457015-9885-8 
Tilman, D.; Cassman, K.G.; Matson, P.A.; Naylor, R.; Polasky, S. (2002). Agricultural sustainability and intensive production practices. Nature. 418(6898): 671-677.

Tischer, A.; Potthast, K.; Hamer, U. (2014). Land use and soil depth affect resource and microbial stoichiometry in a tropical mountain rainforest region of southern Ecuador. Oecologia. 175: 375393. doi: https://doi.org/10.1007/s00442-0142894-x

Tonucci, R.G.; Nair, V.D.; Ramachandran Nair, P.K.; Garcia, R. (2017). Grass vs. tree origin of soil organic carbon under different land-use systems in the Brazilian Cerrado. Plant and Soil. 419(1-2): 281292. https://doi.org/10.1007/s11104-017-3347-1

USDA-NRCS. (2014). Soil survey field and laboratory methods manual. Lincoln, Nebraska: USDA-NRCS.

Villaseñor, D.; Chabla, J.; Luna, E. (2015). Caracterización física y clasificación taxonómica de algunos suelos dedicados a la actividad agricola de la provinica del El Oro. Cumbres. 1(2): 28-34.

Walkley, A.; Black, A. (1934). An examination of the determination method for determining soil organic matter and a proposed modification of the chromic acid titration method. Soil Science. 37: 29-38.

Weil, R.; Brady, N. (2017). The nature and properties of soil. Columbus, HO: Pearson. doi: https://doi.org/ http://lccn.loc.gov/2016008568

Wiesmeier, M.; Urbanski, L.; Hobley, E.; Lang, B.; Lützow, M.; Marin-spiotta, E.; Wesemael, B.; Rabot, E.; Garcia-Franco, N.; Wollschlager, U.; Vogel, H.; Kögel-knabner, I. (2019). Geoderma Soil organic carbon storage as a key function of soils - A review of drivers and indicators at various scales. Geoderma. 333: 149-162. https://doi.org/10.1016/j. geoderma.2018.07.026

Wilcke, W.; Yasin, S.; Abramowski, U.; Valarezo, C.; Zech, W. (2002). Nutrient storage and turnover in organic layers under tropical montane rain forest in Ecuador. European Journal of Soil Science. 53(1): 15-27. doi: https://doi.org/10.1046/j.13652389.2002.00411.x 